\title{
Present Status of Experimental Animals in Japan
}

\author{
Yoshio TAJIMA \\ Nippon Veterinary and Zootechnical College \\ Musashino-shi, Tokyo, Japan
}

\begin{abstract}
The movement for modernization of experimental animals in Japan started around 1950 . Since that time, a quarter of a century has passed. This article outlines the present status of experimental animals in Japan and makes comparisons with various other countries.

Number of animals used: According to three surveys performed in the past (1956, 1960 and 1970), the numbers used of many species are increasing (Table 1). However, it can not be said simply that the numbers are increasing every year. Taking the United States where surveys are performed every year as an example (Table 3), it is evident that the peaks for use of some species are past (the same tendencies were seen in India and Sweden which have conducted more than four surveys in the past (Table 4). The same tendencies would probably also be seen in Japan if surveys were conducted annually.

Quality of animals: It is easy to procure genetically and microbiologically controlled rats and mice. However, investigations into the establishment, production and supply of other species of such high quality are insufficient. This situation is almost the same as that in European countries.

Miscellaneous: The present status of other items related to experimental animals is as follow: Facilities and equipment: Higher level facilities were first provided in companies, followed by testing and research institutes. At present, medical universities are providing such facilities.

Feed: Pellet type diets are widely used for the various species.

Care and management: In April, 1974, "The Law for the Protection and Control of Animals" came into force. This law includes regulations concerning animal experimentation but investigations concerning these standards have just begun.

Training of technicians and specialists: The Japan Experimental Animal Research Association provides a correspondence course, tests and recognition for technicians. About 10 veterinary colleges have undergradunte or postgraduate courses for the training of specialists but these are elective except in two or three cases.
\end{abstract}

\section{わが国ならびに欧米諸国の実験動物の現状}

田 嶋 嘉 雄

実験動物の近代化運動は1950年ごろにはじまった。日 本は，安東洪次博士という先覚者のおかげで，英米両国 とほとんど同時期に，しかも重要なととは独創的に，近 代化運動のスタートをきるととができたわけである。以 来 4 半世紀を経過して今日にいたった。そこで, 実験動 物ならびに関連する事項について，日本の現状をなが め，それを欧米の状況とくらべてみるてとにする。（な お，欧米については断片的な資料しかむっていない。従 って，欧米の状況といっても，乙れまた断片的なあので しかないととを，あらかじめおことわりしておく)。

\section{I 実験動物それ自身について}

\section{1. 動物使用数}

i わが国の現状，ならびに欧米との比較：

わが国の使用数を表 1 亿示した。乙の表は過去 3 回行 なわれた全国調査の成績をまとめたものである。表をみ ると，多くの動物種で年とともに増加の傾向がみられて いる。たとえばマウスについてみる之，127万，245万， そして 1,150 万となっている。しかし，なかには増加の 
Table 1. Number of Experimental Animals Used

\begin{tabular}{|c|c|c|c|c|c|c|}
\hline \multirow{2}{*}{ Species* } & \multirow{2}{*}{$\begin{array}{c}1956 \\
\text { Number }\end{array}$} & \multicolumn{2}{|c|}{1960} & \multicolumn{3}{|c|}{1970} \\
\hline & & Number & $* *$ & Number & $* *$ & $* * *$ \\
\hline Mice & $1,275,442$ & $2,459,683$ & 1.9 & $11,150,143$ & 8.7 & 4.5 \\
\hline Rats & 160,047 & 353,050 & 2.2 & $1,600,643$ & 10.0 & 4.5 \\
\hline Rabbits & 71,762 & 164,714 & 2.3 & 152,917 & 2.1 & 0.93 \\
\hline Guinea Pigs & 67,561 & 121,716 & 1.8 & 144,936 & 2.1 & 1.2 \\
\hline Dogs & 27,486 & 48,570 & 1.8 & 68,052 & 2.5 & 1.4 \\
\hline Cats & 10,154 & 16,465 & 1.6 & 13,757 & 1.4 & 0.84 \\
\hline Sheep - Goats & 4,375 & 12,518 & 2.9 & 18,579 & 4.2 & 1.5 \\
\hline Primates & 99 & 5,361 & 54.2 & 3,526 & 35.6 & 0.66 \\
\hline Hamsters - Eerrets & 3,625 & 4,838 & 1.3 & 21,917 & 6.0 & 4.5 \\
\hline Swine $\cdot$ Horses $\cdot$ Cattle & 2,055 & 4,421 & 2.2 & 14,339 & 7.0 & 3.2 \\
\hline Chickens & 22,459 & 63,280 & 2.8 & 407,637 & 18.2 & 6.4 \\
\hline Other Aves & 5,068 & 5,497 & 1.1 & 74,562 & 14.7 & 13.6 \\
\hline Frogs $\cdot$ Toads $\cdot$ Newts & 96,200 & 152,126 & 1.6 & 150,639 & 1.6 & 0.99 \\
\hline Total & $1,746,333$ & $3,412,239$ & 2.0 & $13,821,647$ & 7.9 & 4.1 \\
\hline Chicken Eggs & & $2,834,175$ & & $43,569,965+$ & & 15.4 \\
\hline
\end{tabular}

*: Adjusted to 1956 Classification Standard.

**: Rate of increase over 1956 (times)

***: Rate of increase over 1960 (times)

Table 2. Number of Experimental Animals Used in Various Countries

Main Mammals

\begin{tabular}{|c|c|c|c|c|c|c|c|c|c|}
\hline Countries & Year & Mice & Rats & Guinea Pigs & Rabbits & Hamsters & Dogs & Cats I & Primates \\
\hline Australia & 1971 & 657,000 & 96,760 & 34,300 & 13,605 & & 2,952 & 600 & \\
\hline Belgium & 1969 & 300,000 & 260,000 & 12,000 & 7,000 & 700 & 2,300 & & 1,000 \\
\hline Canada & $1971 \sim 73$ & $1,063,179$ & 554,568 & 95,326 & 46,880 & 14,390 & 20,973 & 12,670 & 5,128 \\
\hline \multirow[t]{2}{*}{ Finland } & 1956 & 121,942 & 6,402 & 4,492 & 838 & 76 & 57 & 122 & \\
\hline & 1971 & 85,000 & 52,000 & 16,000 & 12,000 & & 900 & 350 & \\
\hline \multirow[t]{3}{*}{ France } & 1957 & 627,232 & 258,133 & 105,830 & 68,915 & 3,990 & 3,479 & 1,403 & 3,497 \\
\hline & 1963 & 734,000 & 227,000 & 137,700 & 62,300 & 13,330 & 10,000 & 4,500 & 700 \\
\hline & 1970 & $2,927,564$ & $1,051,743$ & 261,338 & 95,798 & 57,969 & 15,730 & 8,040 & 1,860 \\
\hline \multirow[t]{3}{*}{ Israel } & 1957 & 223,800 & 113,800 & 4,300 & 7,100 & 4,000 & & & \\
\hline & 1969 & 460,000 & 50,000 & 10,000 & 10,000 & 15,000 & & & \\
\hline & 1971 & 171,500 & 71,500 & 13,000 & 17,000 & 27,000 & 650 & 2,050 & \\
\hline \multirow[t]{2}{*}{ Norway } & 1956 & 11,060 & 8,800 & 610 & 328 & & 65 & 21 & \\
\hline & 1971 & 60,000 & 20,000 & 8,000 & 3,500 & 500 & 50 & 600 & 100 \\
\hline \multirow[t]{3}{*}{ Poland } & 1959 & 123,816 & 17.650 & 27,853 & 13,301 & 898 & 1,308 & 1,622 & 500 \\
\hline & 1963 & 231,700 & 41,000 & 43,000 & 15,000 & 2,700 & & & \\
\hline & 1967 & 245,600 & 57,000 & 50,000 & 26,000 & 6,700 & & & \\
\hline \multirow[t]{2}{*}{ United Kingdom } & 1956 & $1,722,534$ & 328,357 & 190,677 & 38,157 & 8,142 & 3,999 & 8,341 & 1,871 \\
\hline & 1972 & $3,346,800$ & $1,339,300$ & 218,900 & 91,400 & 28,300 & 11.600 & 11,400 & 6,600 \\
\hline
\end{tabular}

Compiled from ICLA Bulletins and Others $[7,8,9 \& 24]$

みられない動物種むある。ウサギ・ネコ・サル類の1960 年と70年の数值がそれを示している。

以上のような全般的にみた使用数増加の傾向は欧米各
国でも同様である（表 2 )。しかし，“年とともに増加の 一途”と単純にいいきるわけにはいかない。そのことは 米国の調査結果から推測される。米国では1965年以来毎 
Table 3. Number of Experimental Animals Used in the United States.

Main Mammals (Compiled from ILAR News)

\begin{tabular}{|c|c|c|c|c|c|c|c|}
\hline Species & 1965 & 1966 & 1967 & 1968 & 1969 & 1970 & 1971 \\
\hline Mice & $\begin{array}{c}23,987,808 \\
(7)\end{array}$ & $\begin{array}{c}27,925,483 \\
\text { (3) }\end{array}$ & $\begin{array}{c}27,013,950 \\
(4)\end{array}$ & $\begin{array}{c}26,749,297 \\
\text { (5) }\end{array}$ & $\frac{* 35,625,304}{(1)}$ & $\begin{array}{c}* 25,687,067 \\
(6)\end{array}$ & $\begin{array}{c}* 30,281,783 \\
(2)\end{array}$ \\
\hline Rats & $\begin{array}{c}9,902,235 \\
(4)\end{array}$ & $\begin{array}{c}7,940,449 \\
(7)\end{array}$ & $\begin{array}{c}9,203,619 \\
(6)\end{array}$ & $\begin{array}{c}* * 10,266,682 \\
(2)\end{array}$ & $\frac{* * 12,321,871}{(1)}$ & $\begin{array}{c}* * 9,870,628 \\
(5)\end{array}$ & $\begin{array}{c}* * 10,204,069 \\
\text { (3) }\end{array}$ \\
\hline Guinea Pigs & $\begin{array}{c}341,160 \\
(7)\end{array}$ & $\begin{array}{l}660,282 \\
\quad(5)\end{array}$ & $\begin{array}{c}847,893 \\
\quad(3)\end{array}$ & $\frac{987,437}{(1)}$ & $\begin{array}{c}888,602 \\
\text { (2) }\end{array}$ & $\begin{array}{c}737,899 \\
\quad(4)\end{array}$ & $\begin{array}{c}464,322 \\
\text { (6) }\end{array}$ \\
\hline $\begin{array}{l}\text { Rabbits } \\
\text { (includ. Hares) }\end{array}$ & $\begin{array}{l}244,700 \\
\quad(7)\end{array}$ & $\begin{array}{l}363,288 \\
\quad(6)\end{array}$ & $\frac{639,145}{(1)}$ & $\begin{array}{c}613,641 \\
(2)\end{array}$ & $\begin{array}{c}576,956 \\
\quad(3)\end{array}$ & $\begin{array}{l}492,792 \\
\quad(4)\end{array}$ & $\begin{array}{c}442,614 \\
(5)\end{array}$ \\
\hline Hamsters & $\frac{1,113,263}{(1)}$ & $\begin{array}{l}838,283 \\
\quad(6)\end{array}$ & $\begin{array}{c}1,093,360 \\
(2)\end{array}$ & $\begin{array}{c}808,988 \\
\quad(7)\end{array}$ & $\begin{array}{c}855,829 \\
(5)\end{array}$ & $\begin{array}{l}870,056 \\
\quad(4)\end{array}$ & $\begin{array}{c}938,065 \\
\text { (3) }\end{array}$ \\
\hline Gerbils & $\begin{array}{l}3,566 \\
(7)\end{array}$ & $\frac{66,197}{(1)}$ & $\begin{array}{l}61,460 \\
(2)\end{array}$ & $\begin{array}{l}58,651 \\
(3)\end{array}$ & $\begin{array}{l}39,940 \\
(6)\end{array}$ & $\begin{array}{l}41,874 \\
(5)\end{array}$ & $\begin{array}{l}49,541 \\
(4)\end{array}$ \\
\hline Dogs & $\begin{array}{l}91,926 \\
(7)\end{array}$ & $\frac{415,159}{(1)}$ & $\begin{array}{c}371,024 \\
\text { (4) }\end{array}$ & $\begin{array}{c}409,472 \\
\quad(2)\end{array}$ & $\begin{array}{c}372,229 \\
\text { (3) }\end{array}$ & $\begin{array}{l}182,728 \\
(6)\end{array}$ & $\begin{array}{c}192,524 \\
\text { (5) }\end{array}$ \\
\hline Cats & $\begin{array}{l}32,301 \\
(7)\end{array}$ & $\begin{array}{l}142,754 \\
\text { (3) }\end{array}$ & $\begin{array}{c}136,749 \\
\text { (4) }\end{array}$ & $\frac{171,322}{(1)}$ & $\begin{array}{c}162,808 \\
(2)\end{array}$ & $\begin{array}{c}56,646 \\
(6)\end{array}$ & $\begin{array}{c}75,935 \\
(5)\end{array}$ \\
\hline Primates & $\begin{array}{c}63,294 \\
(4)\end{array}$ & $\begin{array}{c}62,783 \\
(5)\end{array}$ & $\begin{array}{l}70,416 \\
(2)\end{array}$ & $\frac{85,283}{(1)}$ & $\begin{array}{c}68,004 \\
(3)\end{array}$ & $\begin{array}{c}54,437 \\
(7)\end{array}$ & $\begin{array}{c}56,567 \\
(6)\end{array}$ \\
\hline
\end{tabular}

* Includes Spiny, Deer, etc. $\quad * *$ Includes Kangaroo, Cotton, etc.

Under lined numbers show maximum nmber used. Letters in parentheses indicate rank.

Table 4. Number of Experimental Animals Used

Main Mammals (Countries conducting 4 or more surveys)

\begin{tabular}{|c|c|c|c|c|c|c|c|c|c|c|}
\hline \multirow{2}{*}{ Species } & \multicolumn{6}{|c|}{ India } & \multicolumn{4}{|c|}{ Sweden } \\
\hline & 1957 & 1965 & 1967 & 1968 & 1970 & 1971 & 1956 & 1960 & 1968 & 1970 \\
\hline Mice & 204,965 & 682,779 & 799,770 & 802,271 & $\underline{879,186}$ & 602,646 & 84,600 & 295,000 & 525,000 & 550,000 \\
\hline Rats & 32,507 & 85,445 & 93,668 & 112,409 & 124,423 & 136,484 & 25,900 & 33,400 & 161,000 & 183,000 \\
\hline Guinea Pigs & 16,220 & 20,407 & 16,323 & 18,983 & $\underline{20,733}$ & 15,054 & 48,200 & 86,000 & 112,000 & 110,000 \\
\hline Rabbits & 9,560 & 13,867 & 12,142 & $\underline{15,905}$ & 14,825 & 12,500 & 11,200 & 15,000 & 20,800 & $\underline{24,500}$ \\
\hline Hamsters & 670 & 1,968 & 9,037 & 14,144 & $\underline{17,620}$ & 16,410 & 766 & & & \\
\hline Dogs & 890 & 5,567 & 4,113 & 4,815 & 3,341 & $\underline{5,627}$ & 440 & 1,870 & 3,030 & 3,020 \\
\hline Cats & 600 & 3,358 & 3,448 & 4,287 & $\underline{4,355}$ & 4,272 & 1,007 & $\underline{5,350}$ & 4,675 & 4,800 \\
\hline Primates & 1,897 & $\underline{2,544}$ & 1,521 & 2,513 & 1,099 & 1,424 & 65 & $\underline{4,520}$ & 2,560 & 1,540 \\
\hline
\end{tabular}

Underlined numbers show maximum number used (Compiled from ICAR Bull \& Others $[7,8,9]$ )

年調查を行なっているが, 表 3 はそれを集計したもので ある。表中のカッコ内の数値は使用数についての順位, アンダーラインは最高使用数を示している。てれでみる と, 最高使用数は過去にみられており, マウス・ラット
は 1969, モルモットは 1968，その他の動物種むすべて 1968年以前にある。同様の処見は他の国であみられてい る。表 4 は, 過去に 4 回以上の調査を実施しているイン ド・スエーデンの成績をまとめたあのであるが，米国と 
Table 5. Number of Experimental Animals Used in 1970 : Comparison of Japan, United States and France

\begin{tabular}{|c|c|c|c|c|c|}
\hline \multirow{2}{*}{ Species* } & \multirow{2}{*}{ France $[32]$} & \multirow{2}{*}{ United States [19] } & \multicolumn{3}{|c|}{ Japan } \\
\hline & & & Number & $* *$ & $* * *$ \\
\hline Mice & $2,927,564$ & $25,669,458$ & $11,150,143$ & 3.80 & 0,43 \\
\hline Rats & $1,051,743$ & $9,862,974$ & $1,600,643$ & 1.52 & 0.16 \\
\hline Guinea Pigs & 261,338 & 737,899 & 144,936 & $\underline{0.55}$ & 0.19 \\
\hline Rabbits & 95,798 & 192,792 & 152,917 & 1.59 & 0.31 \\
\hline Hamsters & 57,969 & 870,056 & 21,834 & $\underline{0.39}$ & $\underline{0.02}$ \\
\hline Dogs & 15,730 & 182,728 & 68,052 & 4.32 & 0.37 \\
\hline Cats & 8,040 & 56,646 & 13,757 & 1.71 & 0.24 \\
\hline Primates & 1,860 & 54,433 & 3,526 & 1.89 & $\underline{0.06}$ \\
\hline Other Mammals & 16,954 & 212,424 & 37,049 & 2.18 & 0.17 \\
\hline Aves & 114,355 & 887,253 & 482,199 & 4.21 & 0.54 \\
\hline Reptiles & 1,335 & 90,697 & 4,676 & 3.50 & $\underline{0.05}$ \\
\hline Amphibians & 48,880 & $2,039,490$ & 151,304 & 3.09 & $\underline{0.07}$ \\
\hline Fishes & 79,415 & 519,950 & 244,661 & 3.08 & 0.47 \\
\hline Total Mammals & $4,436,996$ & $38,139,410$ & $13,192,857$ & & \\
\hline Total Vertebrates & $4,680,981$ & $41,676,800$ & $14,075,697+$ & & \\
\hline
\end{tabular}

* Adjusted to French Classification Standard

** Comparison with France (times)

*** Comparison with U. S. A. (times)

同じ傾向を示している。このような処見からむしわが 国でむ毎年調查を実施してお扎ば，最高使用数を過去に もつ動物種が, ウサギ・ネコ・サル類以外にもみられた かむしれない。

つぎに日本の使用数を欧米のそれと比較してみた。比 較の対象はフランスと米国であるが，それはちょうど 1970年の両国の調査報告がだされているからである。米 国は世界でもっとあ多く実験用動物を消費する国であ り，フランスはヨーロッパの実験動物先進国の平均的消 費国とみられる。その比較を表 5 亿示した。表にみるよ うに，日本は大体米国の半数以下の使用数である。10\% 以下を示した動物種をみると，八ムスタ一類，サル類， は虫類, 両生類がある。またフランスとくらべてみる 之，全般的には日本の使用数のほうが多いが，しかしモ ルモットはフランスの半分, 八ムスター類は $40 \%$ 以下で ある。欧米諸国にくらべて，わが国のモルモット・八ム スター類使用数の少ない点（表 2 で, 各国のマウス：モ

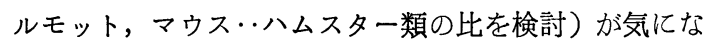
る。
なお1972年の ICLA の総会で，内容の詳細は不明で あるが，ソ聯は毎年医学研究に各種動物合計 2000 万ぐら いにつかい，毎年 $5 \%$ ららいづつふえている，と報告し ている[9]。このような, 使用動物数の合計 (哺乳動物 合計，あるいは脊椎動物合計）の数值をみると，米国は 約 4,000 万前後, ソ聯が 2,000 万, 日本は $1,300 \sim 1,400$ 万，そしてフランスは 450 万前後となる。日本は米国・ ソ聯についで第 3 の実験用動物消費国ということになり そうである。

\section{ii 使用数についての今後の傾向}

以上の各国の調查成績からみると, 実験動物先進国で の動物消費数は大体ピークに達しているように思われる が，その点について考察してみる。

使用数の将来について予測した数值が手元に 2 つあ る。ひとつは古く，1966年に米国の W.B. Saunders \& Co., Economic Consultant のデータで, NIH の資料, 生産者・供給者のサンプリング調査にあとづいてつぎの 数值をまとめた $[16]$ 。1965年消費数としてマウス 3684 万, ラット 1566 万, モルモット 252 万, ハムスター 
類 330 万，ウサギ 156 万（との数值は表 3 のILAR 調 査の数値とはかなり開きがある)・そして 1970 年消費数 の予測として，マウス 5,956 万，ラット 2,532 万，モ ルモット 407 万， ハムスター類 534 万，ウサギ 252 万の数を示した。表 3 の ILAR の1970年消費数はこの 予測值をはるかに下まわっている。との経済コンサルタ ント社の数值の増加傾向と ILAR の実際使用数の増加 傾向とをくらべてみると，1965年から1970年にかけて， モルモット・ウサギが倍増する傾向は一致している。し かしその他の動物種については ILAR の数值では顕著 な増加はみられていない。

いまひとつの例は Academy of Finland の調查結果 にあとづく予測 [14]である。それは表 2 に示した1971年 の数值をむとにして，マウス・ラット・モルモット・ウ サギ・イヌ・ネコの 6 種について，1975・1980の使用数 を予測している。マウス・ラットだけをとりあげてみる と, $1971 \cdot 75 \cdot 80$ 年で， マウスは $85,000,135,000$, 193,000，ラットは52,000，91,000，133,000としてい る。他の 4 種についても同様増加の数值をだしている。 なお，フィンランドは, との調査の時点では微生物統御 された動物についての生産・使用施設はできていない， いうならば，実験動物についての発展途上国ともみられ る国である。

ところで動物使用数の増減にはいくつかの要因が考え られる。增加させる要因としては，使用機関・使用者の 増加と, 新しい動物実験プロジェクトの設定がある。ま た減少させる要因としては，その逆のととがらが働く。 かつて小児マヒワクチンについて，不活化ワクチンが開 発された段階で急激にサル類の使用数が増加したが，生 ワクチンの開発で減少したのは，ての例とみるとともで きよう。な抔用数減少の要因として，動物の質の向 上，実験動物の単純なものへの置き換え（まるごとの動 物から細胞へ), 動物保護運動の進展などああげられよ う。このように考えてみると，大ま玑ついて，実験動 物発展途上国では使用数は堌加するが，実験動物先進国 では必ずしも増加の傾向はみられない，ということにな りそうである。米国は後者, そしてフィンランドは前者 かもしれない。フィンランドの予測が実際にどうなるか 興味があたれるが，それはそれとして，日本はどちらか というと，米国に近いとみられる。

\section{2. 使用動物の質}

i わが国の現状，ならびに欧米との比較：

主な動物種について検討してみるととにする。検討の 項目としては，第 1 亿実験動物化，つまり計画的な繁殖 ·生産がどの程度進展しているか，第 2 亿遺伝的・微生 物的純化，つまり近交系・クローズドコロニーあるいは ノトバイオーッ・SPF がどの程度生産・使用されてい
るか, という点である。比較の対象としては欧米の実験 動物先進国, 米国・英国・フランス・西ドイッ・オラン ダなどの諸国である。

検討の結果，つぎのようにいえそうである。

マウス・ラット：わが国では多くの系統が作出されて いるし，遺伝的統御された動物が一般につかわれてい る。一方微生物統御された動物として SPF が広くつか われている。この 2 種の動物に関するかぎり，わが国の 現状は欧米の先進国に劣っているとはみられない。

モルモット・ハムスター類：わが国では遺伝的統御は 進展し，いくつかの近交系が作出され，乙れらの使用屯 ふえている。しかし微生物統御についてはマウス・ラッ 卜にくらべはるかに遅れており，SPFの作出も確立して いない。欧米では，両種についての SPF が公表され， 使用されている国がある。わが国の現状はいささかおく れているといわざるをえない。

ウサギ：わが国ではまだ実験動物化の過程である。ウ サギの実験動物化は1950年代の初期 [1]に手がつけられ ているが進展がなく，現在むあいかわらず一部において 進められている程度にすぎない。実験につかわれる多く のウサギは家畜の転用，というのが実状である。遺伝的 統御についてみると, ウサギは近親交配がきわめてむず かしい動物で，現在世界的にみても，兄妹交配 20 代以上 の近交系は1·2系しかない。わが国であ1.2近交がつづけ られたが F 20にはいたっていない[22]。しかし，クロー ズドコロニーとして維持生産されているむのがある程度 つかわれている。微生物的統御についてはきわめてわづ かの SPF が生産されている程度で, 多くの実験はコン ベンショナルをつかっているのが実状である。欧米諸国 あ必ずしも進んでいるとはいえないが，わが国よりは先 行しているとみられる。

イヌ・ネコ：わが国ではノライヌ・ノラネコが使用数 の大部分を占める。実験動物化の点で欧米諸国におくれ ている。

サル類：実験動物化はカニクイ $[3] \cdot$ ニホンザル $[35]$ について実施されているが，小型サル類（マーモセット ・タマリン・リスザル・ッパイなど）あとりあげられて いる。しかし全般的にみると，米国はあちろん欧州諸国 よりおくれているように思われる。

トリ類：トリ類の近親交配はきわめてむづかしいとさ れる。そこで血縁係数 $80 \%$ 以上（兄妹交配 4 代以上）を 近交系とよぶことが提唱されている。ところでわが国の 現状をみると，ニワトリではいくつかの系統が作出され クローズドコロニーとして維持・生産されている。また

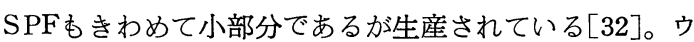
ズラについてあいくつかの系統がつくられている[22]。 これらのトリ類の欧米の現状はわからないが，多分わが 
国と同程度ではなかろうか。つぎにハトについてみる と，わが国では年間 3,000ぐらい使用しているが[38], 実験動物化はまったくとりあげられていない。この点欧 米に大きくおくれているといわざるをえない。

ii 実験動物の質の問題に関連しての登録制ならびに 微生物検查

a 遺伝的統御に関連しての登録制：わが国では実 験動物研究会の系統専門部会（近藤恭司部会長）が1963 年に“実験動物の表示法のとりきめ一一ゥスについて 一一案”を公表して以来検討を重ねてきたが，1973年に 最終決定した表示法[28]を公表した。これはマウスにつ いてのあのであるが，部会はひきつづいてラット・モル モット・ハムスタ一類などについての作業を開始した。 そしてての公表と同時に，近交系マウスの登録受付けを はじめた $[29]$ 。乙の種の遺伝的統御に関しては ICLAも 委員会を編成して（近藤教授が加わっている）作業を実 施し，1972年に outbred の nomenclature を公表した [2]。（この委員会では実験動物を inbred と outbred に大別している。作業は outbred についてであるが, inbred については Staats[33]のそれを採用することに している。なお，ての nomenclature には designation of hyigenic status として, gnotobiote-GN とか SPF を記入するようにしている。また strain という用語は近 交系につかい， outbred には stockという用語を用意 している)。ICLA はこの公表と同時に，世界を 3 つに 区分（米州, 欧州・アフリカ・南西アジア,ならびに東・ 南東アジア。第 3 地域は近藤教授が担当である）し登録 を開始した $[11]$ 。

b 微生物検査に関連して：わが国では実験動物研 究会が疾病部会（藤原公策部会長）を設け1974年以来小 動物についての検討をはじめた。また同じく研究会の無 菌試験についての委員会は試験法の案 [27]を公表し，そ の案について目下委員会で実地に検討をつづけている。 この種の実験動物の感染病ならびにそのチェッキングに ついては欧米諸国であ以前から強力にとりあげており, それについて多くの指導書がだされている（1，2 の例

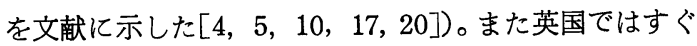
れた認定制度を設け，生産者・供給者の動物のチェッキ ングを実施している)[23]。なお ICLA は Virus Reference Centre[13]を世界の数力所に依嘱し，実験動物の チェッキングを行なうことを計画している。わが国の藤 原公策教授の教室がこの依嘱をうけた機関のひとつであ る。

\section{iii 今後の問題点}

実験につかう動物の質の向上は望ましいことである。 その意味で，わが国ではマウス・ラットばかりでなく他 の動物種についても今後具体的に質について検討する必
要がある。それに関連しててとに 2 つの問題を指摘した い。

第 1 は, 実験目的に応じて質の程度をえらぶことであ る。たとえばマウスをつかう場合，すべての実験に近交 系であり，しかもノトバイオーツに近い高度の SPF で なければならないととはないであろう。またイヌをつか う実験の場合，すべてが䈌正なバリヤーシステムのなか で繁殖・生産されたビーグルでなければならないことも ないはずである。これらの点についての整理はまだでき ていない。

第 2 は, 微生物統御に関連してのワクチンの問題であ る。実験動物には多くの感染症がある。それを排除する ために SPF がつくられる。しかし，いくら厳重なバリ ヤーシステムでの生産であ, 人が直接動物之ふれる限 り, 污染を完全に排除することはできない。施設設備, とりあつかい, 污染系路の遮断などの検討にあわせて, ワクチンの開発を積極的に行なうべきであると考える。 （どの範囲の動物群に実際にワクチンを使うか，という ことは別に検討されることである)。

\section{II 飼育施設・設備ならびに飼料について}

\section{1. 施設・設備}

i わが国の現状ならびに欧米諸国との比較

わが国では，動物舎の空気調和(清浄化を含めて)が必 須である，という考え方は定着した。またバリヤーシス テムあ普遍化している。施設・設備についての日本の進 展についてみると，まず製薬その他の企業体がとりあ げ，つづいて試験研究機関が手をつけ，てれらの機関の 整備は一段落したとみられる。そして現在，医学系の大 学でとりあげている。(しかし大学のうち, 獣医・畜産と か生物系の部門はとり残されているようにみられる。実 験動物学専攻者の大部分が，乙の整備のおくれた部門か らでていることを考えると，気になることである)。

なお，会社・研究機関・大学を含めた全般的なわが国 の現状は欧州の実験動物先進国と同程度で，おくれてい るというととはない。しかし米国とくらべるとおくれて いる。それは米国と日本との組織・機構の整備の程度の ちがいにもとづいているといえよう。米国では施設・設 備についての指導書[18]怔政府から刑行され，各機関は それにもとづいて整備を行なう。そして American Association for Accreditation of Laboratory Animal Care (AAALAC)の認定をうける $[9,18,39]$ 。認定をう けた施設でなければ，NIH の動物実験についての資金 援助はうけられない。（1972年 1 月現在認定をうけた機 関は 172 あるが，多くは企業体，政府・民間の陚験研究 機関である。な䛈科系大学あ多く28を算えるが，獣医 
科系大学はわづかに 2 にどまっている)。このような 組織・機構が米国の施設・設備の整備を促進していると いえよう。

ii 今後の問題

2 つの問題点をとりあげたい。

第 1 は環境因子統御についてのととであるが，たとえ ば温度をどの程度まで厳重に制御すべきか，何を尺度に 制御の必要性の湘定を行なうか，についてはまだ未解決 の問題であり検討されなければならない。

第 2 は, 施設・設備の整備の国家的指導の問 題であ る。米国では指導書があり，かつ認定制度があることを 前述した。その指導書は1963年にはじめて刊行された が，その後増補・改訂をつづけ，1972年には第 4 版[18] として発刊されている。乙の種の刊行物はわが国にああ る。1966年文部省研究班は基準案 [21]を作成公表した。 しかしその後てれの改訂は行なわれないまま今日にいた っている。要するに，それは米国に実験動物センタ一機 構 (Institute of Laboratory Animal Resources) があ り，日本にはそれがない，乙とに原因している。考えさ せられる問題である。

2. 飼 料

i わが国の現状

各種動物について固型飼料が多くつかわれている。ま た給水あ一定の方法で行なわれるようになっている。乙 のようなととは一応の進歩とみてよいであろう。欧米の 先進国あ大体同じであろう。

\section{ii 今後の問題}

原料の入手難，価格の高騰，化学物質その他の污染の 問題は世界共通であるようにみられる。それはそれとし て，ここでとりあげたいことは実験動物科学の立場での 問題である。

栄養ならびに栄養素について，人では栄養必要量（生 命維持に必要な最小限の栄養素・カロリ一量）と栄養所 要量（健康に生活するために採ることが望ましい量）の 概念があり，家畜であ維持飼料と生産飼料の概念があ る。とのような考え方を実験動物の飼料にどうとりいれ るべきか。現在多くの動物種で飼育用と繁殖用の飼料が 製造されているが，前者は上記の栄養必要量に近いもの か，あるいは所要量に近いものか，判然としない。実験 動物飼料の研究者・生産者にお願いしたいととは，あら ためて, 動物の品種・系統・年令 ·性別·生理期との関 連に扔いて, 必要量·所要量を検討してほしいというこ とである。あるいは，実験動物の場合には，人や家畜の 概念をとりいれずに別個に考えるべきであるとするな ら，それなりの整理をしてほしいのである。そのような 基礎的検討のうえにたって，適正な飼料についての具体 的処方嘎の作成が望まれる。
適正な飼料之は, 第 1 亿動物の栄養要求 ·搘好性, 第 2 亿環境因子としての一定性, そして第 3 に経済性，を 総合的に組合せたあのであろう。

\section{III 飼育管理に関連しての動物施設の業務，な らびに飼育管理の基盤になる法律・基準}

\section{1. 動物施設の業務}

i わが国の現状ならびに欧米との比較

動物の飼育管理は適正に行なわれなければならない。 適正とは科学的かつ人道的であること，を意味する。科 学的とはつねに一定であること, 人道的とは動物を正常 ・健康·安寧に維持すること，である。乙のようにみる と, 科学的処置と人道的処置との間には当然矛盾摚着が おこる。それをどのように配慮するかが問題である。現 実には，科学的であるととを第一義的にとりあげるが， しかしつねに人道的配慮を意ならないよう心がける必要 がある。

さて，以上のような基本的な考え方のうえにたって， 動物実験施設・実験動物施設の業務は行なわれるわけで あるが，その具体的内容としてはどのようなものであろ うか。

McPherson [26] は実験動物医学 (Laboratory Animal Medicine) についての獣医師の講習で, 動物施設 の責任者としての獣医師の業務として，サービス業務， 研修業務, 研究業務の 3 項目をあげ，内容の詳細を記述 している。しかしての 3 項目は，単に獣医師に限定され るものでなく，動物施設に職をむつすべての人にあては まるものである。そてで，以下に 3 項目の内容を多少拡 大して整理してみた。

1. サービス業務： 適正な飼育管理の監督・実施の ほかに，実験動物・動物実験についての情報集収・配布 （いうならば，よろず相談所的役割を果すこと）

2. 研修業務： 実験動物技術者の訓練，講習をうけ むつとと

3. 研究・試験業務：研究あるいは試験についての プロジェクト班の一員として動物関係を分担すること。 また，別に独立した立場で実験動物についての研究を専 門的に行なうこと。

この 3 つの業務分野は, 大学, 試験研究機関, 企業体 のどこの施設でも，重点をどこにおくかはともかくとし て，久かすことはできない。

さてわが国の実状をみるとようやく中央的な施設が医 科系大学でもぼつぼつでてきた程度であり，ここにとり あげた業務内容の実施はこれからの問題である。ことを 大学にしぼってみると，わが国の現状は米国よりはるか におくれているようにみられる。米国の医科系大学では 
施設の充実されたものむ多く，そして上記の業務む現実 に実施されているようにみられる。とくに注目したいて とは研究業務についての考え方である。Lang \& Harrells [25]は，医学部には Laboratory Animal Medicine あ るいは Comparative Medicine の部門を設けて,そてで は他の一般の講座 ·教室と同様 bacic academic science がとりあげられるような構成でなければならないこと学 強調している。米国の医科系大学の動物施設はこの方向 にむかって進んでいるようにみられる。

\section{ii 今後の問題}

施設の整備にあわせて業務内容の確立が望まれるわけ であるが，それには，適正な実験動物専攻者・技術者の 適正な配置が必要である。

\section{2. 飼育管理の基盤になる法律・基準}

i わが国の現状と欧米の現状

欧米では飼育管理・とりあつかいを法律で規制する国 がふえているが，わが国も近く仲間入りをするととにな る。

a わが国の現状： 昭和48年, 動物保護及び管理に 関する法律がつくられ，49年 4 月から施行されている。 この法律は, 動物の虐待防止・動物の適正なとりあつか いその他動物の保護に関する事項之, 人の生命・財産 · 身体の安全のための動物の管理に関する事項を定めたも のであり,13条からなっている。第11条は動物を教育, 試 験研究，または生物学的製剂の製造の用その他の科学上 の利用に供する場合の条項で，第 1 項ではできるだけ動 物に苦痛を与えない方法によらなければならないこと， 第 2 項では回復の見込のないものはできるだけ苦痛を与 えない方法で処分しなければならないことをうたい，そ して第 3 項では, 内閣総理大臣は関係行政機関の長と協 議して，よるべき基準を定めることができる，としてい る。またての法律の第12条には動物保護審議会の設置が 定められているが，その審議会は発足している。やがて 内閣総理大臣の諮問をうけて審議会が基準案を答申し， それにもとづいて基準がつくられるととになるであろ う。

この点について実験動物研究会ではワーキンググルー プ（倉益茂実委員長）を編我し, 後述 ICLA の指導書 の内容の検討をはじめることにした。

b 欧米の現状：一般的な動物保護条令は1800年代 に制定施行されている国がある(たとえば英・米)。動 物実験についての法令は英国のように1876年に制定され ている国ああるが，多くは近代にはいってのあのであ る。筆者の手元には英国のあの以外にはドイッ（1933） ならびに米国（1966につくられ1970に改訂）のむのしか ないので，ととで全般的に論ずることはできない。

c ICLA の指導書：1974年 8 月 ICLA は動物実
験についての基準の指導書を公表した $[15]$ 。これは Council of Europe に提出されたものであるが，ての提 出までにはつぎのような経過があったという。Antivivisectionist の団体，つまり動物実験反対論者の団体が, 科学·文化についての欧州共同体ともみられるヨーロッ パ会議 (Council of Europe) に申入れをした。そてで ヨーロッパ会議は実験動物専門家の集りであるICLA に 諮問した。ICLA はこの件について委員会をつくって検 討し,さらに各国の National Member の意見を聴し たうえで案をまとめ，ヨーロッパ会議に答申した。それ が指導書である。

この ICLA の指導書は, 将来とも動物実験をやめる ということはとてもおてりそうにないとと，しかし動物 実験はできるだけ最少限にとどめ，かつ行なう場合には 人道的配慮を欠かさないこと，を基本的な態度として， そのうえにたって具体的な飼育管理・とりあつかいの基 準を規定している。

\section{ii 今後の問題点}

前述したように実験動物研究会で ICLA の指導書の 検討をはじめることにしたが，乙の指導書にもられた基 準の大部分はわが国であうけいれられるものである。そ れはそれとして，やがて，日本にも基準が制定されるこ とになるわけであるが，それは国際的な批判にたえるあ のであると同時に，わが国の実状にそくしたあのである ことが望まれる。

\section{IV 実験動物技術者・専攻者の教育・研修}

\section{1. 実験動物技術者の教育・研修ならびに認定}

i わが国の現状ならびに欧米との比較

飼育技術者は動物にとっては生物環境因子である。従 って，動物との接し方は一定であることが望まれる。そ のような一定の接し方を習得させるためには教育・研修 が必要である。とくに最少限の飼育管理・とりあつかい の方法については義務教育的にあつかう必要がある。

わが国では1972年以来実験動物研究会の教育研修部会 (中川雅郎部会長) が通信教育を開始した。そして認定 部会（鈴木 潔部会長）は1974年には第 1 回の初級認定 試験も行なった。

欧米諸国でも多くの国で技術者の教育・研修が行なわ れている。ICLA は1972年この点についての調査[12]を 行なった。1CLA 加盟国32力国にアンケートを発送し, 29力国から回答がよせられたが，17力国が教育・研修を 実施していることがわかった。以前からすぐれた制度を あつ国として知られている英・米両国 $[36]$ 以外に，オ一 ストラリア・カナダ・ ハンガリー・東ドイッ・西ドイッ ・オランダ・イスラエルなどがすすんでいる。また，英 
・米・西ドイッでは国家レベルの試験が行なわれてい る。なおこの調査によると, 各国のカリキュラムの内容 とか研修期間がまちまちであり, 今後検討を要するとい

う。日本の通信教育はユニークなむのである。

. ii 今後の問題

教育・研修, 試験ならびに認定制度はようやく開始さ れたばかりである。進展させるためには多くの問題があ る。それらを克服して, 認定をうけた技術者が国家レべ ルで確認され，それにみあう待遇をうけ，業務を逐行で きるようにすることが, 実験動物関係者全体に荷せられ た責務であるといえよう。この方向にむかって前進する 努力がはらわれなければならない。

\section{2. 実験動物専攻者}

i わが国の現状ならびに欧米との比較

動物施設の責任者・スタッフあるいは実験動物の研究 者として, 専攻者の要求は増大する傾向にある。それに 対応する教育が行なわれなければならない[6]。

わが国では獣医科大学その他で, 大学あるいは大学院 過程のなかで実験動物科学の講義が実施されているが, 2,3 を除いては選択課目であり, 実習もともなわない。 まことに貧弱である（現在獣医学課程では 6 年制への移 行が検討されているが，それが実現すると実験動物科学 あより明確なかたちでとりいれられることになりそうで ある)。

欧米の状況をみると，欧州ではデンマーク・西ドィッ ・ノルウエーなどでは獣医科の postgraduate で Laboratory Animal Medicine をとりあげているという $[9]$ 。 米国はこの分野ではとくにすすんでいて $[9,36,39]$, 現在16の機関 (主に医科大学の動物施設, その他政府関 係機関。きわめて少数の獣医科大学) で postgraduate, residency-postdoctoral の高度の Laboratory Animal Medicine の研修が行なわれている。

\section{ii 今後の問題}

わが国の獣医 ·畜産教育部門における実験動物の教育 のおくれを，一概にこの部門の無関心さが原因，ときめ つけるわけにはいかない。

その点について，米国を例にとって検討してみよう。 米国でも，前述のように獣医学系の施設整備はおくれて いる。そして, 実験動物専攻者の研修は主として獣医学 系以外の機関で行なわれている。とのととは, 獣医学の 分野で最少限の実験動物に関する教育は行なうが，実際 に必要な実地研修はそれに適する機関で行なうようにな っている，とみられる。

わが国でも前述のように獣医学課程に 6 年制がとりい れられれば, 現在よりは実のある実験動物学が講じられ よう。しかしそれだけでは到底満足されるはずはない。 これらの点をどのように打解するかについての検討が行
なわれなければならない。

\section{V 実験動物の開発・改良}

わが国の現状と欧米の状況をみるととにする。

開発之は野生動物・家畜の実験動物化, 改良とは実験 動物の遺伝的純化あるいは特性の強化を意味する。

この分野について実験動物研究会では $2 つ の$ 専門部会 を編成し検討をつづけているが（新しい実験動物——吉 田俊秀部会長, 疾患モデル——松下 宏部会長), 1975 年から文部省が特定研究として“実験動物の純化と開発” をとりあげられることになり，ようやく開発・改良につ いての本格的な動きがはじまろうとしている。

欧米でも各国でこの分野の研究はとりあげられている ようにみられる。興味のもたれる例としてはライ菌に感 受性をむつというアルアジロ nine-banded armadillo 〔34]とか, わが国の多くの研究者, とくにガン研究とか 免疫学研究にたずさわる人々に大きな関心をむたれてい る nude mouse[ $[30,31]$ がある。なお，米国の病態モデ ル開発についての組織化は注目される[37]。

\section{ま と め}

以上各分野にわたってのべたが，それらをまとめると つぎのようなととになる。

動物使用数は，動物種によっては，今後増加すること はないかもしれない。

動物の質に関連して，今後向上をはからなければなら ない動物種が多い。また微生物統御に関連してワクチン の検討が行なわれるべきであろう。

施設との関連において，狭義の環境因子の統御につい ての再検討が必要であり, 同じことは飼料についてもい える。

害験動物技術者・専攻者についての配慮が必要であ る。

以上のようなことになるが，ふりかえってみると，乙 れらの題目の多くは実験動物近代化運動の初期の段階か らかかげられてきているものであることに気づく。そし てそのことは，実験動物問題の打解が，いかにむづかし いか，いかに根気のいる仕事であるかを，あられめて印 象づけることであある。

[本稿の大要は第 9 回実験動物研究発表会で講演した]

\section{文献}

［1］荒蒔義和·勝俣是五郎 - 小松 稔 ·多田 檀 - 村 田行夫 ·浅倉晴弥・油井 享(1974)：日本白色種 ウサギ系統化の試み-_- “Tokyo-D”ウサギにつ いて。武田研究所報，33，55-62. 
[2] Festing, M., Kondo, K., Loosli, R., Poiley, M. \& Spiegel, A. (1972): International standard nomenclature for outbred stocks of laboratory animals. ICLA Bull., No. 30, 4-17.

[3] 藤原 徹・本庄重男・今泉 清(1969)：カニクイ ザルの実験室内繁殖の実際とその問題点。実験動 物, 18, 29-40.

[4] Geselschaft für Versuchstierkunde(1972): Liste von Erreger zur Spezifierung bei SPF-Versuchstieren. pp. 56.

[5] Geselschaft für Versuchstierkunde(1973): Liste von Nachweismethoden zur Überprüfung von SPF-Versuchstieren auf Freisein von Erregern. pp. 68.

[6]本庄重男(1973)：実験動物医学における獣医的局 面を論じた世界保健機構招集の会議について。実 験動物, 22, 155-159.

[7] ICLA : International Survey on the Supply, Quality and Use of Laboratory Animals. I, 1 $\sim 169$ (1958), Suppl. I III, 170-277, (1959), Suppl. IV, V, 278-542, (1962)

[8] ICLA Bulletin : No. 24 (1969), No. 27(1970) No. 33 (1973), No. 34 (1974).

[9] ICLA Secretariat (1971) : Report of the National, Union, and Scientific Members to the ICLA General Assembly. ICLA Special Reprint, No. 1.

[10] ICLA Virus Reference Laboratory Sub-Committee (1972): The Viruses of Laboratory Rodents and Lagomorphs. pp. 89 with one table.

[11] ICLA (1973): Registration of outbred stocks of laboratory animals. JCLA Bull., No. 32, $17-20$.

[12] ICLA (1973) : ICLA survey of training in laboratory animal technology. ICLA Bull., No. $33,15-20$.

[13] ICLA $(1972 \sim 74)$ : ICLA Bull., No. 31, 25 26 ; No. 34, 30 31; No. 35, 29.

[14] ICLA (1974) : National News. ICLA Bull., No. 34 .

[15] ICLA (1974) : Guideline for the Regulation of Animal Experimentation. ICLA Special Reprint, No. 7, pp. 14.

[16] ILAR (1966) : Estimated laboratory animal consumption 1965-1970. ILAR News, 9, No. 3.

[17] ILAR Committee on Laboratory Animal Res- ources (1971) : A Guide to Infectious Diseases of Mice and Rats. pp. 41, NAS-NRC, Washington.

[18] ILAR (1972) : Guide for the Care and Use of Laboratory Animals. Revised. pp. 56, DH EW Publ. No. (NIH) 73-23.

[19] ILAR (1972): Annual Survey of Animals Used for Research Purposes During Calender Year 1970. ILAR News, 15, No. 2.

[20] ILAR Committee on Laboratory Animal Diseases (1974) : A Guide to Infectious Diseases of Guinea Pigs, Gerbils, Hamsters, and Rabbits. pp. 16, attached to ILAR News, 17, No. 4.

[21］環境調節実験室委員会小動物班 (1966)：実験動物 室の飼育施設の建築および設備設計の基準案。実 験動物, 15, 17-41.

[22] Kuramasu, S. (1973) : Establishment of laboratory animals from several species of domestic animals. Proc. ICLA Asian Pacific Meet. Lab. Anim. Suppl. Exp. Anim., 22, 261-269.

[23] Laboratory Animal Centre (1974): The Accreditation and Recognition Schemes for Suppliers of Laboratory Animals. 2nd Edit., pp. 45.

[24] Laboratory Animal Centre : Survey of the Numbers and Types of Laboratory Animals Used in the United Kingdom in 1972. Manual Series No. 3 MRC-LAC, pp. 16.

[25] Lang, C.M. \& Harrell, G. T. (1972) : Guidelines for a quality program of laboratory animal medicine in a medical school. J. Med. Educat., 47, 267-271.

[26] McPherson, C.W. (1974): Laboratory Animal Medicine-What it is and how to relates to veterinary medicine. Audio-Tutorial Series in Laboratory Animal Medicine.

[27] 日本実験動物研究会 無菌試験の規準に関する委 員会 (1972)：無菌動物の無菌試験法について。実 験動物, $21,35-38$.

[28］日本実験動物研究会系統専門部会(1973)：実験動 物の表示法について。実験動物， $22 ， 37-43$.

[29］日本実験動物研究会系統専門部会(1973)：マウス 近交系の公表について。実験動物, 22,271-273.

[30] Rygaard, J. (1973) : Thymus \& Self. Immunology of the Mouse Mutant Nude. F.A.D.L., 
Copenhageh, pp. 193.

[31] Rygaard, J. \& Povlsen, C. O. (1974): Proceedings of the First International Workshop on Nude Mice. Gustav Fischer Verlog, pp.301.

[32] Sabourdy, M. (1973) : Enquête sur les animaux de laboratoire et les moyens mis à la disposition des unités animales. Expérimentation Animale, 6, 47-59.

[33] Staats, Joan (1968) : Standardized nomenclature for inbred strains of mice : Fourth listing. Cancer Res., 28, 391-420.

[34] Storrs, E. (1972): The nine-banded armadillo. A model for biomedical research. The Laboratory Animal in Drug Testing : 5th ICLA Symp., Hannover, 31-43.

[35] Tanaka, T. \& Kotera, T. (1973) : Breeding of the Japanese monkey on an island as a laboratory animal. Proc. ICLA Asian Pacific Meet. Lab. Anim. Suppl. Exp. Anim., 22, 471 -477 .

[36] 田嶋嘉雄(1964)：諸外国における実験動物問題の 現状。実験動物, 13，148-154.

［37］田嶋嘉雄(1973)：実験動物と動物実験——病態モ デルの開発と国際的動きに関連して。新薬と治 療, 6, No. 9, 3-6.

[38］“わが国における実験動物の生産・供給について の調査・研究”班(1973)：実験につかわれた動物 種ならびにその数—1970年度の調査結果から。 実験動物, 22, 307-340.

[39] Yager, R. H. \& Anderson, M. J. (1973) : Laboratory animal science in United States. Proc. ICLA Asian Pacific Meet. Lab. Anim. Suppl. Exp. Anim., 22, 61-71. 